\title{
ANATOMICAL CHARACTERIZATION OF SELECTED PLANLET Vanilla planifolia Andrews. ON FUSARIC ACID, RESISTANT TO Fusarium oxysporum f. sp. vanillae
}

\author{
Suharyanto E. ${ }^{*}$, Nurcahyani E. ${ }^{2}$, Hadisutrisno $B^{3}$, Sumardi $I^{1}$ \\ ${ }^{1}$ Laboratory of Plant Structure and Development, Faculty of Biology, Gadjah Mada University, Indonesia. \\ ${ }^{2}$ Laboratory of biotechnology, Faculty of mathematic and Sciences, Lampung University, Indonesia. \\ ${ }^{3}$ Laboratory of Agriculture mycology, Faculty of Agriculture, Gadjah Mada University, Indonesia \\ * Email: suharyantoemanuel@gmail.com
}

\begin{abstract}
Vanilla is one of the important agricultural export commodity of Indonesia. The vanilla from Indonesia is well known for it high levels of vanillin content,which is about 2,75\%. Until recently, the most hazardous disease of vanilla is foot rot infection caused by Fusarium oxysporumf. sp.vanillae (Fov). One alternative way to control the foot rot disease is by using cultivars which resistant to its pathogen. Selected plantlets have been induced by using fusaric acid on the in vitro medium. The goal of this research is to characterize the anatomical point of few especially on leaves, pseudo bulb and root with respect of resistant to Fov. Moreover, it is also addressed to determine the different characters of the phenotype vanilla plantlet whichare total of phenol, peroxydases enzyme activity, the thickness of lignin, and the chlorophyll content. The data on this research were recorded, compiled and categorized as descriptive qualitative and quantitative information. Theresult showed significant increase in chlorophyll a, chlorophyll b, and also the total of chlorophyll. The overall in line correlated with the increasing FA concentration. The total chlorophyll at $90 \mathrm{ppm}$ FA could increased about 1,2 times, while at $100 \mathrm{ppm}$ and $110 \mathrm{ppm}$ FA could enhanced about 1,4 to 1,5 times compared to control. Anatomical characters between vanilla control, infected fov, and resistant to fov, were showed clearly at the stele part especially at xylem as the main function for transporting water from root to the leaf, which formed thyllose. Phenol total at about 4,39\% in control, increased to 5,34\% in $90 \mathrm{ppm}$, and followed by $5,52 \%$ in $100 \mathrm{ppm}$ and $5,87 \%$ at $110 \mathrm{ppm}$. Peroxidases enzyme activity at FA $90 \mathrm{ppm}$ produced about $0,25 \mathrm{U} / \mathrm{mg} / \mathrm{min}$, and at $100 \mathrm{ppm} F A$ on $0,34 \mathrm{U} / \mathrm{mg} / \mathrm{min}$, while at FA $110 \mathrm{ppm}$ generated $0.36 \mathrm{U} / \mathrm{mg} / \mathrm{min}$ compared to control, at $0,12 \mathrm{U} / \mathrm{mg} / \mathrm{min}$. The thickness of lignin tracheid in the treatment of $90 \mathrm{ppm}$ was at about 14,59 ìm; 100 ppm 18,16 ìm; and 110 ppm 19,39 ìm compared to controls 10,28 ìm. In conclusion over all showed that FA induced plantlet vanilla inin vitro medium resulted in change of phenotype compare to control, which also affect its anatomy structure, especially on lignification and thyllose formation at surrounding tracheids, which could be use as marker for defend mechanism of plant to Fov.
\end{abstract}

Key words: Fusarium oxysporumf. sp. Vanillae, peroxydases enzyme, anatomical characters.

\section{INTRODUCTION}

Sub-sector plantation from agriculture has played important role in order to elevate national economical growth. This sector contribute on foreign exchange value and also work plan (Anonymous, 2010). Vanilla (Vanilla planifolia Andrews) is an industrial plantation, which is planted at tropical countries including Indonesia, as export commodity (Hadipoentyanti et al., 2007). Indonesian vanilla, Java Vanilla Beans is widely known for itshigh production and best quality. It is contain about $2,75 \%$ vanillin, followed by Madagaskar vanillin $(1,91$ 1,98\%), Sri Langka (1,48\%), and Mexico (1,89-1,98\%)(Hadisutrisno, 2004). United Nations Development Programme (UNDP), ranked Indonesian vanilla in the same level as Bourbon vanill, which has already known at international vanilla market for its quality (Umamaheswari \& Mohanan, 2011). This is an advantage for enhancement of Indonesian vanilla export and increasing farmer income (Barani, 2008).Vanillin is used in food or beverages, medicinal beverage, and in aromatic perfume industries as raw materials(as tincture

ISSN 2413-0877 @ 2015 The Authors.

Published by KnowledgeE Publishing Services This is an open access article under the CC BY-NC-ND license (http://creativecommons.org/licenses/by-nc-nd/4.0)

Selection and Peer-review under responsibility of the 3rd ICBS-2013

Doi http://dx.doi.org/10.18502/kls.v2i1.164 
or absolute form) (Mengesha, 2012).Vanilla productivity level in Indonesia was not stable. Therefore, it is required hugequantity plantlet, which was resistant to Fusarium oxysporum f.sp. vanillae (Fov.). One alternative way is to grow a new cultivar, which is resistant to Fov., and also high yield product (Tombe, 2010).

Foot root disease on pseudo bulb of vanilla (BBV) is the main constrain for production of vanilla fruit caused by Fov, which affected $50-100 \%$ death plant. Although some of them still survives, butcauses lower quality of product (Hadisutrisno, 2004). This disease, usually spread via storage plantlet from vegetative breeding, which has already $7-32 \%$ infected Fov.microspores during propagation (Tombe, 2010).

An alternative method to encompase that constrain is using fusaric acid (5-nbutylpicolinic acid) as a metabolite resulted from Fusarium as a selective agent to the plantlets explants. At concentration above $10^{-5} \mathrm{M}$, the fusaric acid could hinder respiration at mitochondria and also sitokinin oxidation process. In addition, it is also decrease Adenosin Tri Phosphat (ATP) on plasma membrane as well as reduction on polifenol activity so hinder plant growth and regeneration. Contrastly, concentration below of $10^{-6} \mathrm{M}$, could induce fitoaleksin sintesis, as plant response for pathogenic activity inhibition (Bouizgarneet al., 2006). This kind of plant defence mechanism would be expressed after patogen attachement (Huang, 2001). Such parameters could be measured including: increasing fenolic coumpound as well as increasing peroxsidaseactivity (PR-protein), also lignifications especially at xylem wall (Lea \& Leegod, 1999). There is positive correlation between resistance plantlet to FA with resistance plantlet to Fusarion respectively (Arai \& Takeuchi, 1993). Such researchs identification in vitro insensitif variety plantlet to FA was done on tomato (Toyoda et al., 1984), banana (Matsumoto et al., 1995), gladiolus (Remotti et al., 1997), and ananas (Borraset al., 2001), which showed that these clones were also resistant to pathogen. Similar experiments on vanilla, were also reported by Kosmiatin et al.(2000), and Inayati (2003), but their result still un-stable yet.

In this context FA possibly would affect the changing of base promoter and trigger the expression of peroxidase gene (Saravanan et al., 2004). Then this protein could be identified by Sodium Dodecyl Sulphate-Polycrylamide Gel Electrophoresis (SDS-PAGE) according to Maniatis et al. (1982). Beside that, genetic variety on vanilla plantlet could be detected by molecular marker, Randomly Amplified Polymorphic DNA (RAPD), which base on Polymerase Chain Reaction (PCR) with 10 bases random primer (Williams et al., 1990). This research was aims to get a selected plantlet AF and characterized base on morphological, physiological and anatomical perspective.

\section{MATERIALS AND METHODS}

Preliminary study was done on in vitro micropopagation of vanilla nodus using MS medium plus 2,4-Dichlorophenoxy Acetic Acid (2,4-D), Naphthalene Acetic Acid (NAA), and Benzyl aminopurine (BAP) (Rout et al., 2006). Phenolic compound has estimated for resistant vanilla and the control by using the method of Aberouman \& Deokule, 2008. Chlorophyll content was measured using plantlet leaves between controlsin the company of resistant vanilla plantlet according Harbourne (1987). This analysis was including the total chlorophyll, chlorophyll a and Chlorophyll b respectively. Protein and DNA profiling also have 
been detected. Character anatomical as the main concerned was showed in the pictures. It also another character which supported this research has been added as supplementary results.

\section{RESULTS AND DISCUSSION}

\section{Characterisation of resistant planletvanili}

Theresults showed that a combination of 2,4-D 2,0 mg/L plus NAA $10 \mathrm{mg} / \mathrm{L}$ was the most effectives for callus initiation and shoot development from shoot tip explants and the BA $1,0 \mathrm{mg} / \mathrm{L}$ was the fastest shoot initiation from a nodes explants. Nodal indeed was the best explant for vanilla plantlet regeneration. In one node explants could produce 3 to 6 shoots within 12 weeks. The increased of capability in nodal explants to form shoot is probably caused by the exsistent of axillaries meristem, so the explants easily regenerated to form shoots. The optimum concentration of FA on plantlet selection with vanilla steady growth was between $90 \mathrm{ppm}-110 \mathrm{ppm}$. They showed yield in plantlet vanilla at about $17,14 \%$ at $90 \mathrm{ppm}$, $12,00 \%$ at $100 \mathrm{ppm}$ and $10,59 \%$ at $110 \mathrm{ppm}$, all of them insensitive to FA. FA insensitive plant may occurred as result of higher expression peroxidase enzymes on variety of resistant plantlet for detoxification. By using FA concentration of $110 \mathrm{ppm}$ was already effective for suppression of Fov growing up to $25 \%$, compared to the concentration of $90 \mathrm{ppm}$ and $100 \mathrm{ppm}$ respectively. In other words by using 110 ppmfusaric acid, it could increased the category criteria from sensitive to resistant. Molecular analysis throughout a protein (SDS PAGE) and DNA (RAPD) pattern proved that Plantlet characters of vanilla indeed resistant to Fov. The protein profile of vanilla plantlet showed a thicker band of about $18 \mathrm{kD}$ compared to the control. We predicted this band like patogen related (PR)-protein may be as the peroxides protein (enzyme), which was responsible for vanilla resistant to Fov. A new band of Random Amplified Polymormhic DNA in a resistant plantlet were found in size of $930 \mathrm{bp}$ by using (OPB_14) primer, 430 bp (OPB_20), 230 bp and 270 bp (OPD_19) respectively. These bands predicted as a candidate marker RAPD which responsible for vanilla resistant to Fov. Actually by increasing FA concentration would enhance also the total phenol, peroxides enzyme activity, and thickness of lignin in vanilla resistanct to Fov. Elevated levels of total phenol of about $4,39 \%$ in control, increased to $5,34 \%$ in $90 \mathrm{ppm}$, followed by $5,52 \%$ in $100 \mathrm{ppm}$ and $5,87 \%$ at $110 \mathrm{ppm}$ Harniet al.(2012). The peroxides enzymes activity enhanced at about 2 to 3 times at 90-110 ppm FA concentrations compared to the control.

According Fahn, (1991) in monocot, the bundle sheat there was no cambium except in the some family of Liliales and this bundle sheat spread in the stele. That's why the stem of monocot relatively constant in the size one to another and could not develop anymore (Dickison, 2000). Lignin was formed as a plant response to the fusarium in order to prevent further damage at epidermal and thracheal parts (Raven et al., 1999). The root of vanilla showed that xylem is consisted oftrachea, tracheids, fibers and parenchyma and located in the stele like some finger print so called diarch, triarch and polyarch. Xylem consist of protoxilem located at the perifer and metaxylem located to the central. The thickness of lignin in the resistant plantlets was increased about 1.4 times at $90 \mathrm{ppm}, 1.8$ times at $100 \mathrm{ppm}$; and 1.9 times at $110 \mathrm{ppm}$ compared to the control. At non-toxic concentrations $\left(10^{-7}\right) \mathrm{FA}$ would induced the $\mathrm{H}_{2} \mathrm{O}_{2}$ from peroxisome organel inside of the cells (Agrawalet al. 1999). 
This peroxide was a compound which could trigger the increase of peroxides enzymes activity and these enzymes possibly would oxidized phenol compound and catalyzed this compound reaction to quinone compounds, which produced $\mathrm{H}_{2} \mathrm{O}_{2}$ that naturally toxic to pathogen (Bouizgarne et al., 2006). Peroxides enzyme plays an important role as regulator catalyst for biosynthesis inducing lignin.

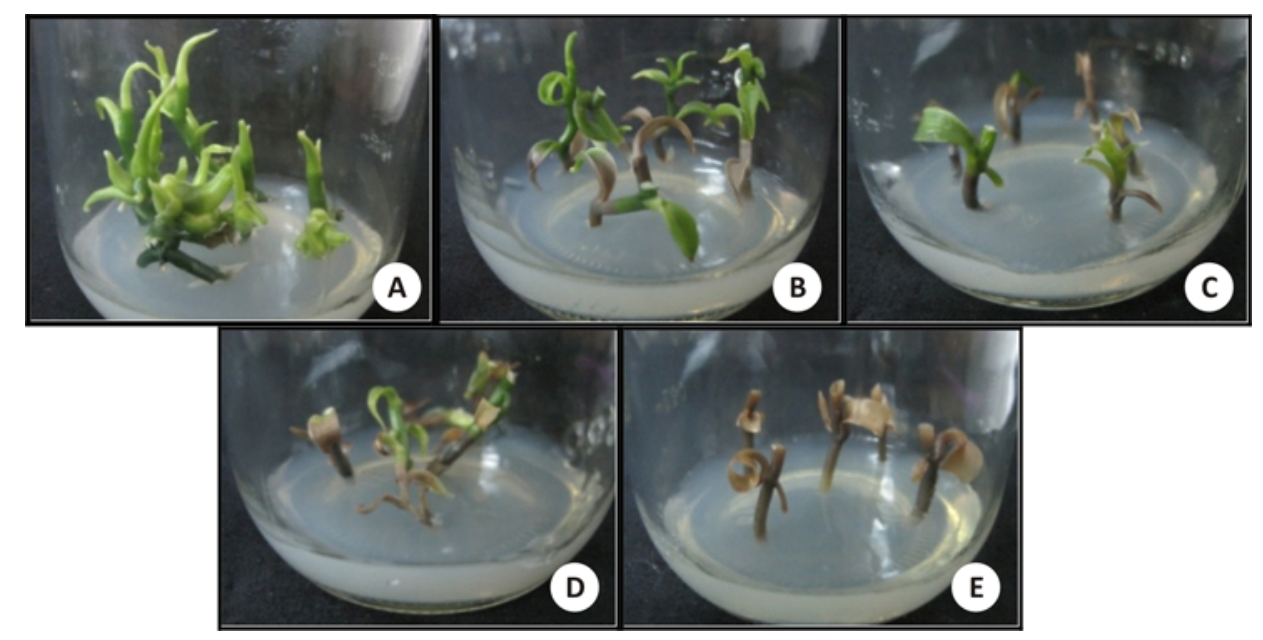

Figure 1. Vanilla plantlet 12 weeks on different fusaric acid concentration $A=0$ ppm (control), green all, $B=90$ ppm, green to few brown, $C=100$ ppm green and a little brown, $D=110$ ppm green to brown, $\mathrm{E}=120 \mathrm{ppm}$, browness
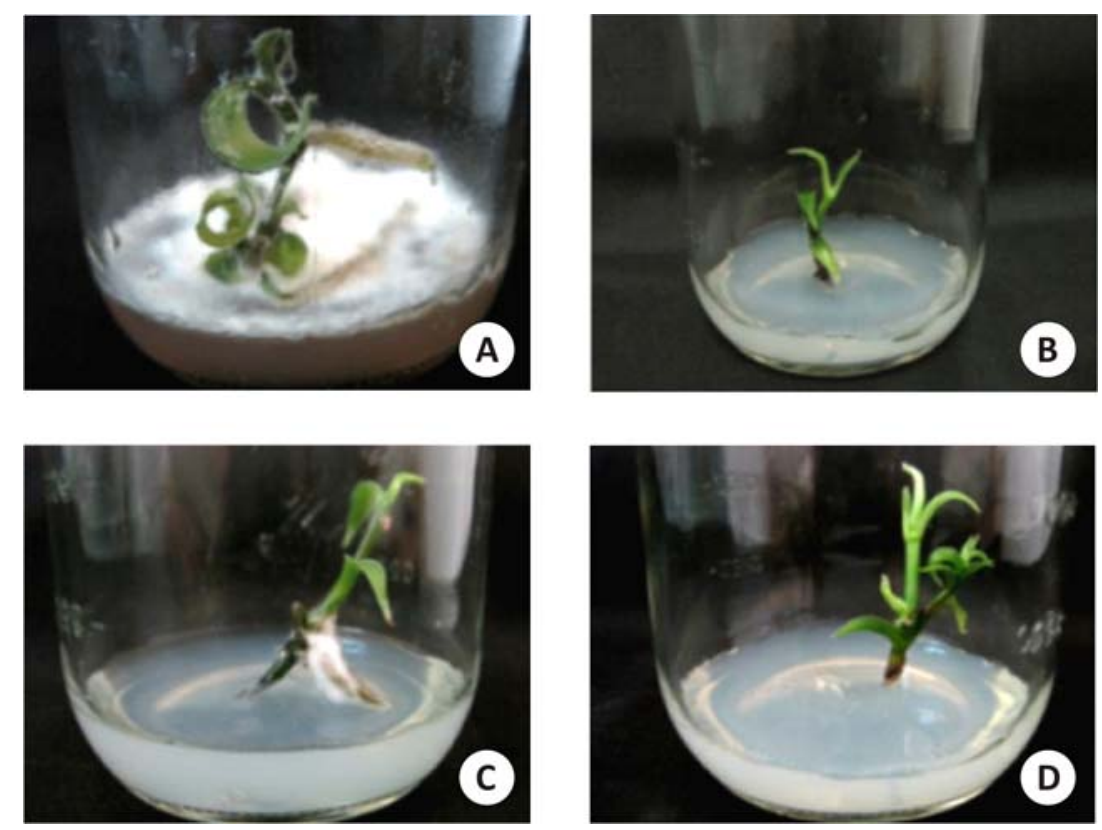

Figure 2. Infected of $F$. oxysporumf.sp. vanillaeon vanilla plantlet at different FA concentration 29 days after selection. $A=0$ ppm, totally die, $B=90 \mathrm{ppm}$, no infection, $C=100 \mathrm{ppm}, \mathrm{n}$ o infection, $D=110$ ppm, no infection 

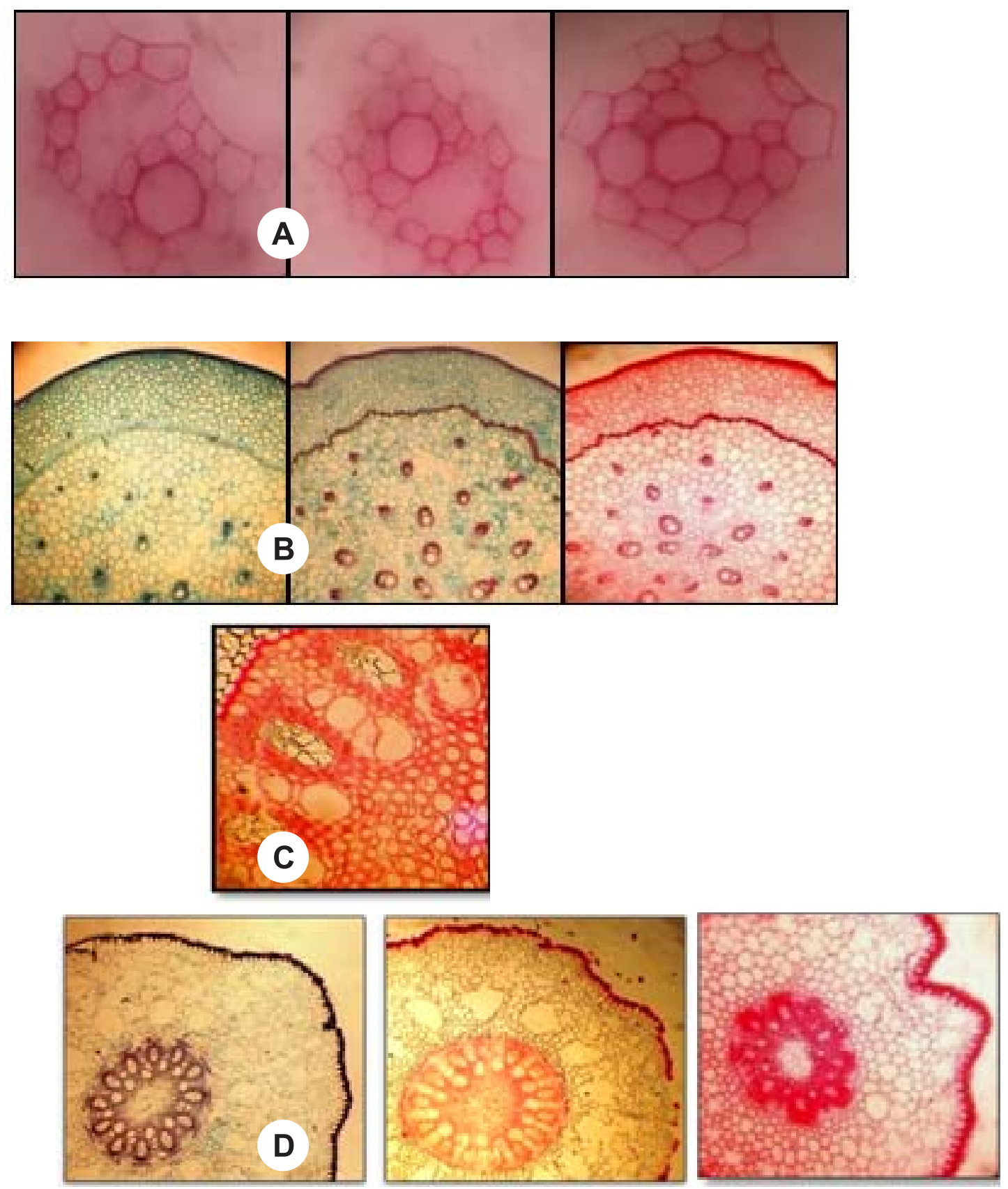

Figure 3. These picture A, B, and D from left to right was: uninfected fov (control), infected to fov. and resistant to fov. A. Lignification on different bundle sheatpart for detection the lignin thickness B. Cross section of vanilla pseudobulb showed amiloplast located between cortex and stele part as an analogous of cambium at dicotyl stem C. Cross section ofinfected to fov. showedthyllose at xylem at thracheid lumen consisted with parenchymes tissue D. cross section of root uninfected, infected to fov. and resistant to fov.From outside to inside: epidermal root showed lignifications at $U$ shape character, parenchymcortex, endodermal, floem, xylem, pith.

There was significant increased in total chlorophyll at about 1.2 to 1.5 times compared to the control. This phenomenon in the plantlet proved that it was because of FA pressures, underwent adaptation and changed the basa structures of promoter for toxin $\left(\mathrm{H}_{2} \mathrm{O}_{2}\right)$ detoxification, through activated peroxides gene, affected increasing of the chlorophyll in resistant plantlet. 
This research was supported by Suharyanto et al.(2007) about threonindeaminase defektif (TD) Nicotiana plumbaginifolia mutant complemented by cDNA TD tomato, resulted an increase twice more at the transgenic, even phenotypically better then those mutant.Starvation experiment also was reported from isolated Nicotiana sylvestris mutant resistant to $\beta$-Aminoethylcystein (AEC) when on medium supplemented by isoleusin, lysine, danvalin, and homozigot progeny showed better morphological and physiological growth than control (Suharyanto; personal communication, Frankard et al., 1992).

The anatomical comparison between vanilla plantlet uninfected, infected, and resistant to Fov, showed on xylem as the main water transportation. The metaxylem root lumen formed new parenchymas and was called thylose. These outgrowth tilosis as parenchyma growth in the xylem may be doe to of mechanical respons to the presence of pathogen infection, and served to limit the pathogens. Daly (2006) reported how thylose was formed by Fusarium oxysporum f.sp. cubense (Foc) infected at banana stem. First at all, fungi infected in the form chlamidospors penetrated via root injure and then those spores went to xylem by water transport. Later spores would germinate to form micellium in which give a signal to the cell and peroxisomes produce peroxides. Xylem formed parenchymals in the lumen of tracheids was thyllose to prevent water containing spores for further transport to the stem. Finally, plant would die because supply of water and mineral was blocking (Semangun, 2001).

\section{CONCLUSION}

The anatomy comparison between uninfected Fov, infected Fov, and resistant to Fov, vanilla viewed from part of the stele. They located on xylem as the main transportation. Metaxylem roots forms new parenchyma's in the xylem lumen named tilosis. These outgrowth tilosis in the xylem probably is a form of mechanical response to the presence of pathogen infection, and it is function to isolate the pathogens. In general, the increasing of fusaric acid concentration used for selection are followed by enhancing of phenolic compound, peroxides enzyme activity, chlorophyll content and thickness of lignin in epidermal as well as in surrounding tracheids.

\section{REFERENCES}

Aberouman, A.A., and S.S. Deokule. 2008. Comparison of Phenolic Compounds of Some Edible Plants of Iran and India. Pakistan Journal of Nutrition 7: 582-585.

Agrawal, A.A., S. Tuzun, and E. Bent. 1999.Induced Plant Defenses AgaintsPhatogens and Herbivores, Biochemistry, Ecology, and Agriculture. APS Press, St. Paul, Minnesota. $390 \mathrm{p}$.

Anonymous (FAOSTAT). 2010. Foodand Agricultural Commodities Production. http:// faostat.fao.org/site/339/default.aspx. Accessed 6 Desember 2011.

Arai, M., and M. Takeuchi. 1993. Influence of Fusarium Wilt toxin(s) on Carnation cell. Plant Cells, Tissue and Organ Culture (34): 287 - 293.

Barani, A.M. 2008. 23\% Produksi Vanili Dunia Dihasilkan Indonesia. Kapanlagi.com. http:/ /www.merdeka.com/ekonomi/nasional/23-produksi-vanili-dunia-dihasilkan-indonesiazpxafbm.html. Accessed 21 September 2011. 
Boras, O., R. Santos, A. Matos, P. Cabral, and R.S. Arzola. 2001. A First Attempt to Use A Fusarium subglutinans Culture Filtrate For The Selection of Pineapple Cultivar to Fusariose Disease. Plant Breeding 120(5): 345-438.

Bouizgarne, B., H.E.M. Bouteau, C. Frankart, D. Reboutier, K. Madiona, A.M. Pennarun, M. Monestiez, J. Trouverie, Z. Amiar, J. Briand, M. Brault, J.P. Rona, Y. Ouhdouch, and E.I. Hadrami. 2006. Early Physiological Responses of Arabidopsis thaliana Cells to Fusaric Acid : Toxic and Signallling Effects. New Phytologist 169: 209-218.

Daly, A. 2006. Fusarium Wilt of Bananas (Panama Disease).Northern Territory Government. USA.

Dickison WC. 2000. Integrative Plant Anatomy. Academic Press. USA.

Fahn, A. 1991. AnatomiTumbuhan. $3^{\text {rd }}$ edition. UGM Press. Yogyakarta.

Frankard, V., M. Ghistain, and M. Jacobs. 1992. Two Feedback-Insensitive Enzymes of The Aspartate Pathway in Nicotianasylvestris. Plant Physiol.

Hadipoentyanti, E., A. Ruhnayat, and L. Udarno. 2007. Booklet Teknologi Unggulan Tanaman Perkebunan:Vanili. Pusat Penelitiandan Pengembangan Perkebunan. 21 p. Hadisutrisno, B. 2004. Taktik dan Strategi Perlindungan Tanaman Menghadapi Gangguan Penyakit Layu Fusarium.SimposiumNasional I, 2-3 Maret 2004 di Purwokerto.

Harbourne, J.B. 1987. Metode Fitokimia. Penerbit ITB Bandung. pp: 259-261.

Harni, R., Supramana, M.S. Sinaga, Giyanto, and Supriadi. 2012. Mekanisme Bakteri Endofit mengendalikan nematoda Pratylenchus brachyurus Pada Tanaman Nilam. Bul. Littro23 (1): 102-114.

Huang, J.S. 2001. Plant Patogenesis and Resistance, Biochemistry and Physiology of Plant-Microbe Interactions. Kluwer Academic Publisher. Dordrecht. $516 \mathrm{p}$.

Inayati, A. 2003. Seleksi Ketahanan Tunas Vanili Terhadap Fusarium oxysporumf.sp.vanillae Secara In Vitro MenggunakanTeknik Double Layer, Kultur Filtrat, dan Asam Fusarat. Tesis. (Tidak dipublikasikan).

Kosmiatin, M., I. Mariska, A. Husni, Y. Rusyadi, Hobir, and M. Tombe. 2000. Seleksi Silang Ketahanan Tunas In Vitro Panili Terhadap Asam Fusarat dan Ekstrak Fusarium oxysporum. Jurnal Bioteknologi Pertanian 5(2): 77-83.

Lea, P., and R.C. Leegood.1999. Plant Biochemistry and Molecular Biology. $2^{\text {nd }}$ ed. John Wiley \& Sons Ltd. Chichester. $364 \mathrm{p}$.

Maniatis, T., E.F. Fritsch, and J. Sambrook J. 1982. Molecular Cloning. A Laboratory Manual. Cold Spring Harbor Laboratory, Printed in The United States of America.

Matsumoto, K., M.L. Barbosa, L.A.C. Souza, and J.B. Teixeira. 1995. Race 1 Fusarium Wilt tolerance on banana plants selected by Fusaric Acid. Euphytica 84: 67-71.

Mengesha, A., B. Ayenew, E. Gebremariam, and T. Tadesse T. 2012.Micro-Propagation of Vanilla planifolia Using Enset (Ensete ventricosum (Welw, cheesman)) Starch as a Gelling Agent. Current Research Journal of Biological Sciences 4(4): 519-525.

Raven, P.H., R.F. Ever, and S.E. Eichorn. 1999. Biology of Plants. $6^{\text {th }}$ Edition. WH. Freeman \& Company Worth Publisher. USA.

Remotti, P.C., H.J.M. Löfler, and L.V. Loten-Doting. 1997. Selection of Cell Lines and Regeneration of Plants Resistance to Fusaric Acid from Gladiolus x grandiflorus c.v. 'Peter Pear'. Euphytica 96: 237 - 245. 
Rout, G.R., A. Mohapatra, and M.S. Jain. 2006. Research Review Paper: Tissue Culture of Ornamental Pot Plant: A Critical Review on Present Scenario and Future Prospects. Biotechnology Advances 24: 531- 560.

Saravanan, T., R. Bhaskaran, and M. Muthusamy. 2004.Pseudomonas fluorescens Induced Enzymological Changes in Banana Roots (Cv. Rasthali) against Fusarium Wilt Disease. Plant Pathology Journal 3: 72-80.

Semangun, H. 2001. Pengantar IImu Penyakit Tumbuhan. Gadjah Mada University Press. Yogyakarta.

Suharyanto, E., M. Vautein, and M. Jacobs. 2007.Contribution Towards a Better Human Prosperity. Proceeding International Seminar Advances in Biological Science. Yogyakarta. pp. 13, 170.

Tombe, M. 2010. Teknologi Ramah Lingkungan Dalam Pengendalian Terpadu penyakit Busuk BatangVanili (BBV)- Orasi Pengukuhan Profesor Riset Bidang Fitopatologi (Hama dan Penyakit Tanaman). Badan Penelitian dan Pengembangan Pertanian, Kementrian Pertanian, Jakarta. http://pustaka.litbang.deptan.go.id/berita.b 100405b.pdf. Accessed 14 June 2010.

Toyoda, H., H. Hayashi, and K. Yamamoto. 1984. Selection of Resistance Tomato Calli to Fusaric Acid. Ann. Phytophatol. Soc. Japan.50: 538-540.

Umamaheswari, R., and K.V. Mohanan. 2011. A Study of the Asociation of Agronomic Characters in Vanilla planifolia Andrews. International Journal of Plant Breeding and Genetics 5 (1): 53-58.

Williams, J.G.K., A.R. Kubelik, K.J. Livak, J.A. Rafalski, and S.V. Tingey. 1990. DNA Polymorphism Amplified by Arbitrary Primers Useful as Genetic Markers. Nucl. Acids. Res. 18: 6531-6535. 